\title{
Azadinium obesum (Dinophyceae), a new nontoxic species in the genus that can produce azaspiracid toxins
}

\author{
Urban Tillmann $^{1 *}$, Malte Elbrächter ${ }^{2}$, Uwe John ${ }^{1}$, Bernd Krock $^{1}$ And Allan Cembella ${ }^{1}$ \\ ${ }^{1}$ Alfred Wegener Institute for Polar and Marine Research, Am Handelshafen 12, D-27570 Bremerhaven, Germany \\ ${ }^{2}$ Deutsches Zentrum für Marine Biodiversitätsforschung, Forschungsinstitut Senckenberg, Wattenmeerstation Sylt, Hafenstr. \\ 43, D-25992 List/Sylt, Germany
}

\begin{abstract}
Tillmann U., Elbrächter M., John U., Krock B. And Cembella A. 2010. Azadinium obesum (Dinophyceae), a new nontoxic species in the genus that can produce azaspiracid toxins. Phycologia 49: 169-182. DOI: 10.2216/09-35.1

The novel dinoflagellate taxon we describe here as Azadinium obesum sp. nov. was isolated as clone 2E10 from the North Sea along the Scottish east coast, the same locality as for Azadinium spinosum Elbrächter et Tillmann, the type and formerly only species for this genus. In contrast to $A$. spinosum, a known producer of azaspiracid (AZA) toxins, the isolate of $A$. obesum produces no known AZA analogues detectable by liquid chromatography coupled with tandem mass spectrometry. Azadinium obesum is a small (13-18 $\mu \mathrm{m}$ length; 10-14 $\mu \mathrm{m}$ width) photosynthetic dinoflagellate with a thin theca exhibiting the Kofoidean plate tabulation: Po, cp, X, 4', 3a, 6", 6C, 5? S, 6'", 2'"'. This species is morphologically distinguished from $A$. spinosum by slightly larger mean cell size, consistent absence of an antapical spine, the lack of a stalked pyrenoid and several details of the plate configuration. Among these thecal features, the first precingular ( $\left(1^{\prime \prime}\right)$ plate of $A$. obesum does not touch the first epithecal intercalary plate and is four sided rather than five sided as in A. spinosum. Furthermore, in A. obesum the lower half of the first apical ( $\left.1^{\prime}\right)$ plate is very narrow and tonguelike, and precingular plates $1 "$ and 6" are very close together, whereas these diverge in A. spinosum. DNA sequence and phylogenetic analysis elucidates and supports the separation (but close affinity) of A. obesum and A. spinosum, as well as the description of the former as a distinct species. Phylogenetic interpretation of the four genes analysed - internal transcribed spacer, 18S rDNA, 28S rDNA (D1/D2) and cytochrome oxidase I - further validates the recently erected genus Azadinium Elbrächer et Tillmann but does not clarify the position of the genus with respect to higher taxonomic levels within the subclass Peridiniphycidae.
\end{abstract}

Key Words: Dinoflagellates, Taxonomy, Phylogeny, New species, Azadinium

\section{INTRODUCTION}

Azaspiracids (AZAs) are a relatively recently discovered group of lipophilic marine biotoxins associated with human incidents of shellfish poisoning. After the first case of human poisoning in 1995 (McMahon and Silke 1996), AZA toxins have been reported from several countries mainly of western Europe but also from Morocco (Satake et al. 1998; Ito et al. 2002; James et al. 2002; Magdalena et al. 2003; Taleb et al. 2006; Vale et al. 2008). Considerable work has been done to understand the chemistry, toxicology and ecology of azaspiracid shellfish poisoning (AZP) (recently reviewed by Twiner et al. 2008). However, it took about a decade before the first correct and unambiguous identification of an organism responsible for production of azaspiracids (Krock et al. 2009, Tillmann et al. 2009). The species, a small photosynthetic dinoflagellate, described as Azadinium spinosum Elbrächter \& Tillmann, was isolated from coastal waters off the Scottish east coast but was also detected by molecular methods in samples taken from the Danish coast (Krock et al. 2009), indicating a wide distribution in the North Sea. Azadinium spinosum, a new species in a newly erected genus, clearly belongs to the subclass Peridiniphycidae; however, neither morphology nor phylogeny was able to provide sufficient and conclusive

\footnotetext{
*Corresponding author (urban.tillmann@awi.de).
}

arguments for a definite placement of $A$. spinosum at higher taxonomic levels (Tillmann et al. 2009).

The successful isolation of $A$. spinosum was facilitated by the targeted guidance of liquid chromatography coupled with tandem mass spectrometry (LC-MS/MS) screening of a large number of raw cultures on the presence of azaspiracids (Krock et al. 2008, 2009). Here we report the isolation and identification of a dinoflagellate species from one of the raw cultures found to be negative in the AZA-screening but which attracted attention by a swimming pattern identical to that described for A. spinosum. Further morphological and molecular analysis revealed this isolate as a representative of a new species within the genus Azadinium, which does not produce AZAs in measurable amounts.

\section{MATERIAL AND METHODS}

\section{Isolation and culture of the dinoflagellate}

The culture of Azadinium obesum sp. nov., provisionally designated as dinoflagellate isolate $2 \mathrm{E} 10$, was established from a water sample collected in June 2007 by Niskin bottle from a rosette sampler cast in the North Sea along the Scottish east coast at $57^{\circ} 3.9^{\prime} \mathrm{N}, 02^{\circ} 30.2^{\prime} \mathrm{W}$, the type locality for $A$. spinosum. From a prescreened (20- $\mu \mathrm{m}$ Nitex gauze) sample, three dilutions $(1: 10,1: 100,1: 400)$ were prepared with sterile-filtered seawater $(0.2-\mu \mathrm{m}$ VacuCap filters, 
Dreieich, Germany) from the same station and enriched with 1/10-strength K-medium (Keller et al. 1987). From each dilution, four 96-well plates were filled with $200 \mu 1$ per well. Plates were sealed with parafilm and incubated at $10^{\circ} \mathrm{C}$ and at a photon flux density of $c .20 \mu \mathrm{mol} \mathrm{m} \mathrm{m}^{-2} \mathrm{~s}^{-1}$ (16:8-h light:dark photocycle) in a controlled environment growth chamber throughout the cruise. After the cruise, cultures were transferred to a laboratory incubator maintained at $15^{\circ} \mathrm{C}$ and $50 \mu \mathrm{mol} \mathrm{m} \mathrm{m}^{-2} \mathrm{~s}^{-1}$ on a $16: 8-\mathrm{h}$ light:dark photocycle.

The main aim of the serial dilution setup was to isolate potential producers of azaspiracids (Krock et al. 2009). Screening for toxins of the crude plankton cultures initiated on board ship revealed that only one multispecies culture contained AZA. Later on, a dinoflagellate from this well was isolated in unialgal culture and described as $A$. spinosum Elbrächter \& Tillmann (Tillmann et al. 2009). A large number of other crude cultures negative in the azaspiracid screening were still maintained but without attracting further interest until a cursory microscopic screening at low magnification revealed small dinoflagellate cells in one well with a swimming pattern typical for the newly characterized A. spinosum (Tillmann et al. 2009). Pure unialgal cultures of the small dinoflagellate present in this well were prepared by transferring and washing groups of individual cells by microcapillary into wells of 96-well plates with 1/10-strength K-medium. As soon as subcultures were free of autotrophic contaminants, culture volume was gradually increased, and cultures were routinely kept in 70-ml tissue culture flasks containing 1/10strength K medium (Keller et al. 1987), supplemented with selenite (Dahl et al. 1989), but without addition of $\mathrm{NH}_{4}^{+}$. The growth medium was prepared from sterile-filtered (VacuCap $0.2 \mu \mathrm{m}$ Pall Life Sciences) natural North Sea water (salinity: $32 \mathrm{psu}, \mathrm{pH}$ adjusted to 8.0). Experimental cultures for photosynthetic pigment and toxin analysis were grown separately in Erlenmeyer flasks at $20^{\circ} \mathrm{C}$ under a photon irradiance of $25 \mu \mathrm{mol} \mathrm{m}^{-2} \mathrm{~s}^{-1}$ on a 16:8-h light:dark photocycle.

\section{Light microscopy}

Observation of live cultured cells was carried out with a stereomicroscope (Olympus SZH-ILLD) and with an inverted microscope (Axiovert 200 M, Zeiss, Germany) equipped with epifluorescence and differential interference contrast optics. Light microscopic examination of the thecal plate tabulation was performed on formalin-fixed cells $(1 \%$ final concentration) stained with calcofluor white (Fritz \& Triemer 1985). The shape and localisation of the nucleus was determined after staining of formalin-fixed cells for $10 \mathrm{~min}$ with 4'-6-diamidino-2-phenylindole $\left(0.1 \mu \mathrm{g} \mathrm{ml}{ }^{-1}\right.$ final concentration). Photographs were taken with a digital camera (Axiocam MRc5, Zeiss, Germany) connected to the inverted microscope.

\section{Scanning electron microscopy}

For examination of thecal plates by scanning electron microscopy (SEM), cells from growing cultures were fixed, prepared and collected on $3-\mu \mathrm{m}$ polycarbonate filters
(Millipore) as described by Tillmann et al. (2009). Filters were mounted on stubs, sputter-coated (Emscope SC500, Ashford, UK) with gold-palladium and viewed under a scanning electron microscope (FEI Quanta FEG 200, Eindhoven, Netherlands). Some SEM micrographs were presented on a black background using Adobe Photoshop 6.0 (Adobe Systems, San Jose, CA, USA). Cell size of $A$. obesum was measured from SEM images of whole cells and was compared to cell size of $A$. spinosum determined by the same image analysis method (Tillmann et al. 2009). SEM stubs used for micrographs shown in the figures were numbered and archived at the Alfred Wegener Institute, Bremerhaven, Germany.

\section{Morphological description and taxonomic assignment}

We adopted the general dinoflagellate classification scheme proposed by Fensome et al. (1993) for the assignment of this novel taxon. In describing the thecal plate tabulation, we employed the nomenclature of Kofoid (1909). The designation of the putatively subdivided thecal plates is directly adopted from Morrill \& Loeblich (1981).

\section{Photosynthetic pigment analysis}

The pigment profile as a potential phenotypic marker was analyzed by liquid chromatography coupled to diode array detection (LC-DAD) by spectroscopy. At a cell concentration of $2.2 \times 10^{4}$ cells $\mathrm{ml}^{-1}$ (determined by microscopical cell counts), $60 \mathrm{ml}$ of culture were gently filtered upon a glassfibre filter (GF/C, Whatman, Kent, UK). The filter was immediately shock-frozen in liquid nitrogen and stored at $-20^{\circ} \mathrm{C}$ for $10 \mathrm{~d}$ before being analyzed. Pigments were extracted and analysed as described in Tillmann et al. (2009).

\section{Chemical analysis of azaspiracids}

The close putative taxonomic relationship between $A$. obesum and the known AZA-producer $A$. spinosum warranted an intensive analysis for the presence of AZAs. After 2 wk of growth, $6 \times 50 \mathrm{ml}$ of $A$. obesum culture were harvested at a cell concentration of $3.5 \times 10^{4} \mathrm{ml}^{-1}$, determined by microscopical cell counts. Samples were centrifuged (Eppendorf 5810R, Hamburg, Germany) at $3220 \times g$ for $10 \mathrm{~min}$ in 50-ml Falcon tubes. Cell pellets were combined in a Eppendorf microtube and again centrifuged (Eppendorf 5415, 16,000 $\times g, 5 \mathrm{~min}$ ). The cell pellet was suspended in $500 \mu \mathrm{l}$ methanol, and transferred into a FastPrep tube containing $0.9 \mathrm{~g}$ of lysing matrix D (Thermo Savant, Illkirch, France). The sample was homogenized by reciprocal shaking at maximum speed $\left(6.5 \mathrm{~m} \mathrm{~s}^{-1}\right)$ for $45 \mathrm{~s}$ in a Bio101 FastPrep instrument (Thermo Savant, Illkirch, France). After homogenization, samples were centrifuged (Eppendorf $5415 \mathrm{R}$ ) at $16,100 \times g$ at $4^{\circ} \mathrm{C}$ for $15 \mathrm{~min}$. The supernatant $(400 \mu \mathrm{l})$ was transferred to a $0.45-\mu \mathrm{m}$-pore-size spin filter (Millipore Ultrafree, Eschborn, Germany) and centrifuged for $30 \mathrm{~s}$ at $800 \times \mathrm{g}$. The filtrate was transferred into an LC autosampler vial for LC-MS/MS analysis.

The sample was analysed for azaspiracids by LC-MS/MS according to the methods described in detail by Tillmann et al. (2009). Multiple reaction monitoring (MRM) experiments were carried out in positive ion mode by selecting the 
Table 1. Selected substitution model parameters obtained with Modeltest version 3.7 (Posada \& Crandall 1998; Posada \& Buckley 2004) for each of the four marker regions utilized in this study.

\begin{tabular}{|c|c|c|c|c|c|c|}
\hline Marker & $\begin{array}{l}\text { Length of } \\
\text { alignment }\end{array}$ & $\begin{array}{c}\text { AIC } \\
\text { model }^{1}\end{array}$ & Base frequencies & $\begin{array}{l}\text { Base substitution } \\
\text { frequencies }{ }^{2}\end{array}$ & $\begin{array}{l}\text { Proportion of } \\
\text { invariable sites (I) }\end{array}$ & $\begin{array}{l}\text { Gamma distribution } \\
\text { shape parameter }(\alpha)\end{array}$ \\
\hline SSU & 1044 & $\mathrm{GTR}+\mathrm{I}+\mathrm{G}$ & $\begin{aligned} \mathrm{A} & =0.2787 \\
\mathrm{C} & =0.1713 \\
\mathrm{G} & =0.2552 \\
\mathrm{~T} & =0.2948\end{aligned}$ & $\begin{array}{l}A \Leftrightarrow C=1.0012 \\
A \Leftrightarrow G=4.1105 \\
A \Leftrightarrow T=1.3222 \\
C \Leftrightarrow G=0.6423 \\
C \Leftrightarrow T=9.2563\end{array}$ & 0.3426 & 0.5099 \\
\hline LSU & 449 & $\mathrm{GTR}+\mathrm{G}$ & $\begin{array}{l}\mathrm{A}=0.2337 \\
\mathrm{C}=0.1958 \\
\mathrm{G}=0.2783 \\
\mathrm{~T}=0.2922\end{array}$ & $\begin{array}{l}A \Leftrightarrow C=0.6389 \\
A \Leftrightarrow G=2.5942 \\
A \Leftrightarrow T=0.9062 \\
C \Leftrightarrow G=0.5688 \\
C \Leftrightarrow T=5.7956\end{array}$ & 0.0820 & 0.7419 \\
\hline ITS & 538 & $\mathrm{GTR}+\mathrm{I}+\mathrm{G}$ & $\begin{array}{l}\mathrm{A}=0.2281 \\
\mathrm{C}=0.2035 \\
\mathrm{G}=0.2477 \\
\mathrm{~T}=0.3207\end{array}$ & $\begin{array}{l}A \Leftrightarrow C=0.7557 \\
A \Leftrightarrow G=2.5567 \\
A \Leftrightarrow T=1.1170 \\
C \Leftrightarrow G=0.6039 \\
C \Leftrightarrow T=4.2067\end{array}$ & 0.0363 & 0.8373 \\
\hline $\mathrm{COI}$ & 620 & $\mathrm{GTR}+\mathrm{G}$ & $\begin{aligned} \mathrm{A} & =0.2623 \\
\mathrm{C} & =0.1811 \\
\mathrm{G} & =0.1266 \\
\mathrm{~T} & =0.4300\end{aligned}$ & $\begin{array}{l}A \Leftrightarrow C=1.4505 \\
A \Leftrightarrow G=2.5285 \\
A \Leftrightarrow T=1.9068 \\
C \Leftrightarrow G=2.7492 \\
C \Leftrightarrow T=1.8572\end{array}$ & - & 0.8468 \\
\hline
\end{tabular}

\footnotetext{
${ }^{1}$ Akaike information criterion.

${ }^{2}$ Relative to $G \Leftrightarrow T$ set at 1.0000 .
}

following transitions (precursor ion $>$ fragment ion): (1) AZA-1 and AZA-6: $\mathrm{m} / \mathrm{z} 842>824$ collision energy (CE): 40 $\mathrm{V}$ and $m / z 842>672 \mathrm{CE}: 70 \mathrm{~V}$ ), (2) AZA-2: $m / z 856>838$ CE: $40 \mathrm{~V}$ and $m / z 856>672 \mathrm{CE}: 70 \mathrm{~V}$, (3) AZA-3: $m / z 828$ $>810 \mathrm{CE}: 40 \mathrm{~V}$ and $\mathrm{m} / z 828>658 \mathrm{CE}: 70 \mathrm{~V}$, (4) AZA-4 and AZA-5: $m / z 844>826 \mathrm{CE}: 40 \mathrm{~V}$, (5) AZA-7, AZA-8, AZA-9 and AZA-10: $\mathrm{m} / z$ $858>840 \mathrm{CE}$ : $40 \mathrm{~V}$ and (6) AZA11 and AZA-12: $\mathrm{m} / \mathrm{z} 872>854 \mathrm{CE}: 40 \mathrm{~V}$.

\section{Molecular phylogenetic analysis}

EXTRACTION OF GENOMIC DNA: A 10-ml sample of an exponentially growing culture of $A$. obesum isolate 2E10 was centrifuged (Eppendorf 5810R) at $3220 \times g$ for $15 \mathrm{~min}$ at room temperature. The cell pellet was frozen at $-20^{\circ} \mathrm{C}$ for $20 \mathrm{~min}$ before subjected to total DNA extraction with the DNeasy Kit (Mini) (Qiagen, Hilden, Germany) according to manufacturer's instructions. The purity and quantity of the DNA was checked by UV spectroscopy with a NanoDrop ND-1000 system (Peqlab, Erlangen, Germany), and the integrity of DNA fragments of a molecular weight of about $20 \mathrm{~kb}$ was verified on a $0.8 \%$ agarose gel.

PCR AMPLIFICATION AND SEQUENCING: The extracted total DNA from the $A$. obesum isolate $2 \mathrm{E} 10$ was subjected to polymerase chain reaction (PCR) amplification of the following genes: $18 \mathrm{~S}$ ribosomal DNA, 28S ribosomal DNA (D1/D1 region), internal transcribed spacer (ITS) and cytochrome oxidase subunit 1 (COI). The forward and reverse primers for amplification of full length $18 \mathrm{~S}$ rDNA were $1 \mathrm{~F}$ (5'-AAC CTG GTT GAT CCT GCC AGT-3') and 1528R (5'-TGA TCC TTC TGC AGG TTC ACC TAC-3'), respectively. The forward and reverse primers for
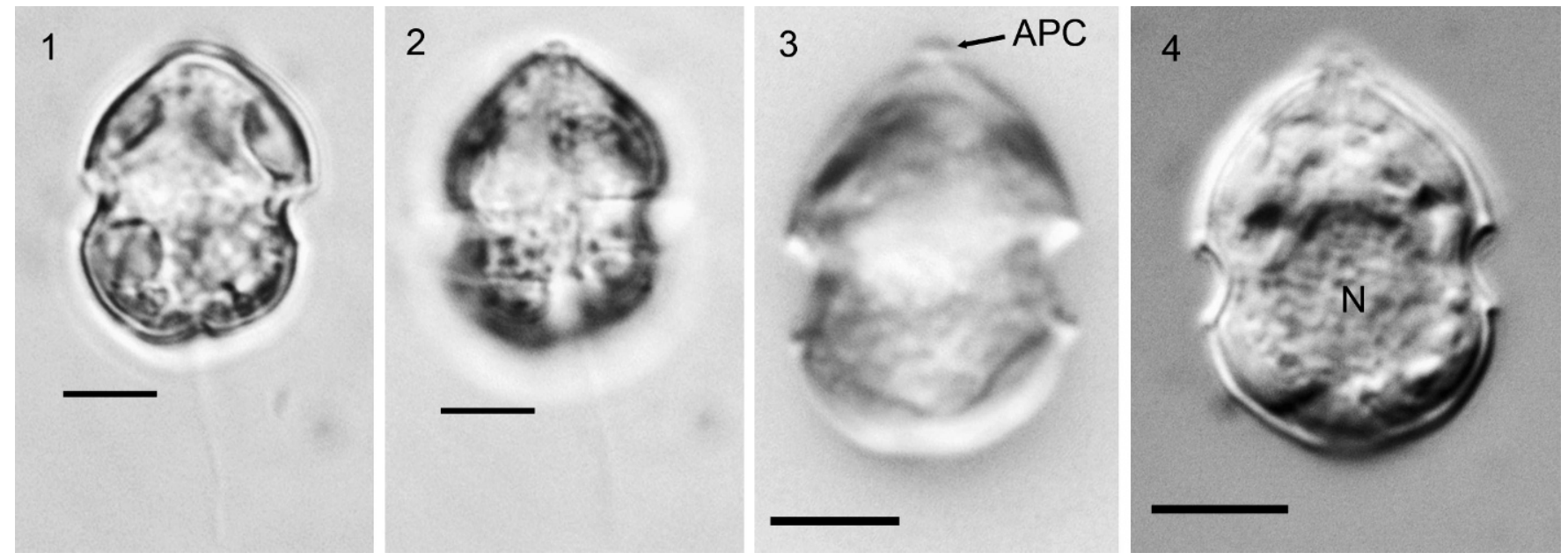

Figs 1-4. Azadinium obesum. Light microscopy. Scale bar $=5 \mu \mathrm{m}$.

Figs 1, 2. Light microscopy of live cells.

Figs 3, 4. Light microscopy of formalin-fixed cells. APC $=$ apical pore complex; $N=$ nucleus. 

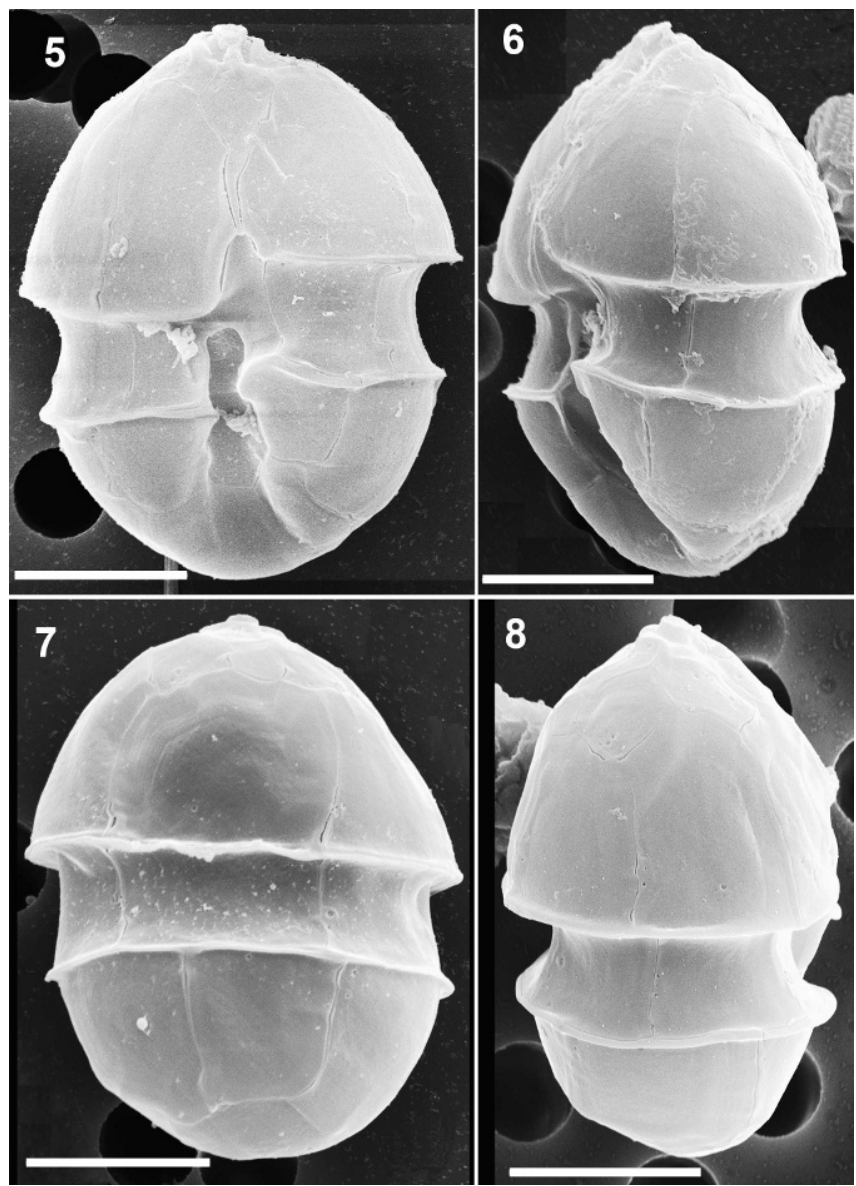

Figs 5-8. Azadinium obesum. SEM pictures of thecae of different cells (from 14/02/08-3 and 14/02/08-5). Scale bar $=5 \mu \mathrm{m}$.

Fig. 5. Cell in ventral view (14/02/08-3).

Fig. 6. Cell in left-lateral view (14/02/08-5)

Fig. 7. Cell in dorsal view $(14 / 02 / 08-3)$.

Fig. 8. Cell in right-lateral view (14/02/08-5).

amplification of 28S rDNA (D1-D2 regions) were Dir-F (5'-ACC CGC TGA ATT TAA GCA TA-3') and Dir-2CR (5'-CCT TGG TCC GTG TTT CAA GA-3'), respectively. The forward and reverse primers for amplification of the ITS region were ITS a (5'-CCA AGC TTC TAG ATC GTA ACA AGG (ACT)TC CGT AGG T-3') and ITS b (5'-CCT GCA GTC GAC A(GT)A TGC TTA A(AG)T TCA GC(AG) GG-3'), respectively. The following primers were used for amplification of the cytochrome oxidase 1 (COI) gene: COIF (5'-AAAAATTGTAATCATAAACGCTTAGG-3') and COIR (5'-TGTTGAGCCACCTATAGTAAACATTA-3') (Zhang et al. 2005).

For each 50- $\mu 1$ PCR reaction, HotMasterTaq (Eppendorf) buffer $1 \times, 0.1 \mathrm{mM}$ of dNTPs, $0.1 \mathrm{mM}$ of each forward and reverse primer and 1.25 units of Taq polymerase were added to $10-30 \mathrm{ng}$ of the extracted genomic DNA.

For $18 \mathrm{~S}$ and $28 \mathrm{~S}$ rDNA amplifications, the reactions were subjected to the following thermocycling conditions: an initial denaturation at a temperature of $95^{\circ} \mathrm{C}$ for $7 \mathrm{~min}$ was followed by 35 cycles of denaturation at $94^{\circ} \mathrm{C}$ for $45 \mathrm{~s}$, annealing temperature at $54^{\circ} \mathrm{C}$ for $2 \mathrm{~min}$ and elongation temperature at $72^{\circ} \mathrm{C}$ for $1.5 \mathrm{~min}$. A final extension step at $72^{\circ} \mathrm{C}$ was carried out for $10 \mathrm{~min}$.

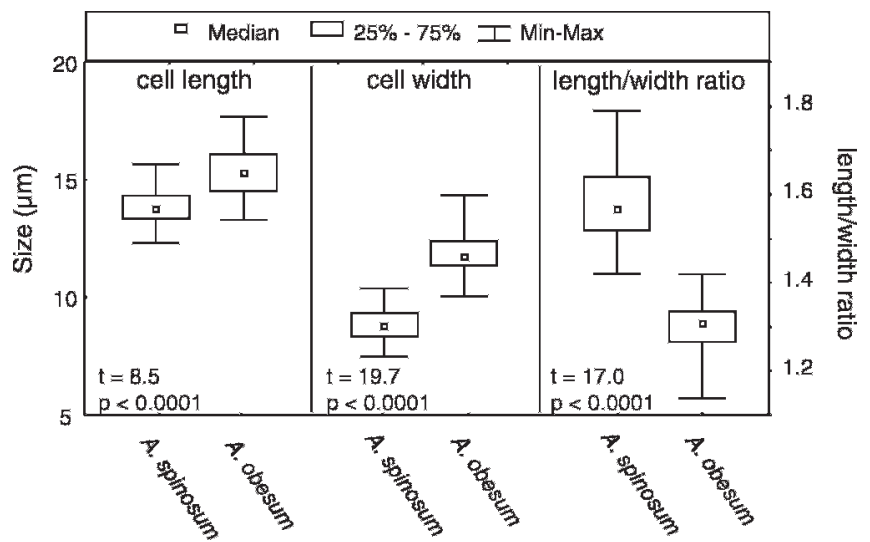

Fig. 9. Size of Azadinium obesum as measured from SEM pictures ( $n=36$ ), compared to size of $A$. spinosum $(n=73)$. $T$ test statistics for the comparison are given in the lower left part of each graph.

For ITS amplifications, the reactions were subjected to the following thermocycling conditions: an initial denaturation at a temperature of $94^{\circ} \mathrm{C}$ for 4 min was followed by nine cycles of denaturation at $94^{\circ} \mathrm{C}$ for $50 \mathrm{~s}$, annealing temperature at $60^{\circ} \mathrm{C}$ for $40 \mathrm{~s}$ and elongation temperature at $72^{\circ} \mathrm{C}$ for $1 \mathrm{~min}$, then 29 cycles of denaturation at $94^{\circ} \mathrm{C}$ for $45 \mathrm{~s}$, annealing temperature at $50^{\circ} \mathrm{C}$ for $45 \mathrm{~s}$ and elongation temperature at $72^{\circ} \mathrm{C}$ for $1 \mathrm{~min}$. A final extension step at $72^{\circ} \mathrm{C}$ was carried out for $5 \mathrm{~min}$.

For COI amplifications, the reactions were subjected to the following thermocycling conditions: an initial denaturation at a temperature of $94^{\circ} \mathrm{C}$ for 3 min was followed by 39 cycles of denaturation at $94^{\circ} \mathrm{C}$ for $30 \mathrm{~s}$, annealing temperature at $46^{\circ} \mathrm{C}$ for $30 \mathrm{~s}$ and elongation temperature at $70^{\circ} \mathrm{C}$ for $1 \mathrm{~min}$. A final extension step at $70^{\circ} \mathrm{C}$ was carried out for $5 \mathrm{~min}$.

The completed reactions for all of the above amplifications were kept at $10^{\circ} \mathrm{C}$ until the next step. The PCR amplicons were analyzed on $1 \%$ agarose by electrophoresis.

SEQUENCE ALIGNMENT FOR PHYLOGENETIC ANALYSES: Sequence alignment was done with CLUSTAL $X$ software (Thompson et al. 1997) and improved manually for all sequences; ambiguous alignments positions were excluded for the analysis. Alignments are available upon request, and sequences are available at GenBank under accession numbers GQ914935 (SSU), GQ914936 (LSU), FJ766093 (ITS), and GQ914937 (COI). Maximum likelihood phylogenetic trees for all genes were calculated with PhyML (Guindon \& Gascuel 2003) using a BIO-NJ (neighbourjoining) tree as a starting tree, the WAG evolutionary model (Whelan \& Goldman 2001), with a gamma distribution parameter estimated from the data. For the SSU, LSU, and ITS of rDNA and the COI, we used Oxyrrhis marina Dujardin as out-group. An optimal base substitution model was calculated with Modeltest (Posada \& Crandall 1998; Posada \& Buckley 2004) (Table 1).

Nodal support was estimated by bootstrap analyses (Felsenstein 1985) using maximum parsimony (MP) and NJ using the AIC model parameters described above (Table 1). The bootstrap analyses were done in 1000 replicates for MP and NJ and with 100 replicates for the maximum likelihood analysis. 

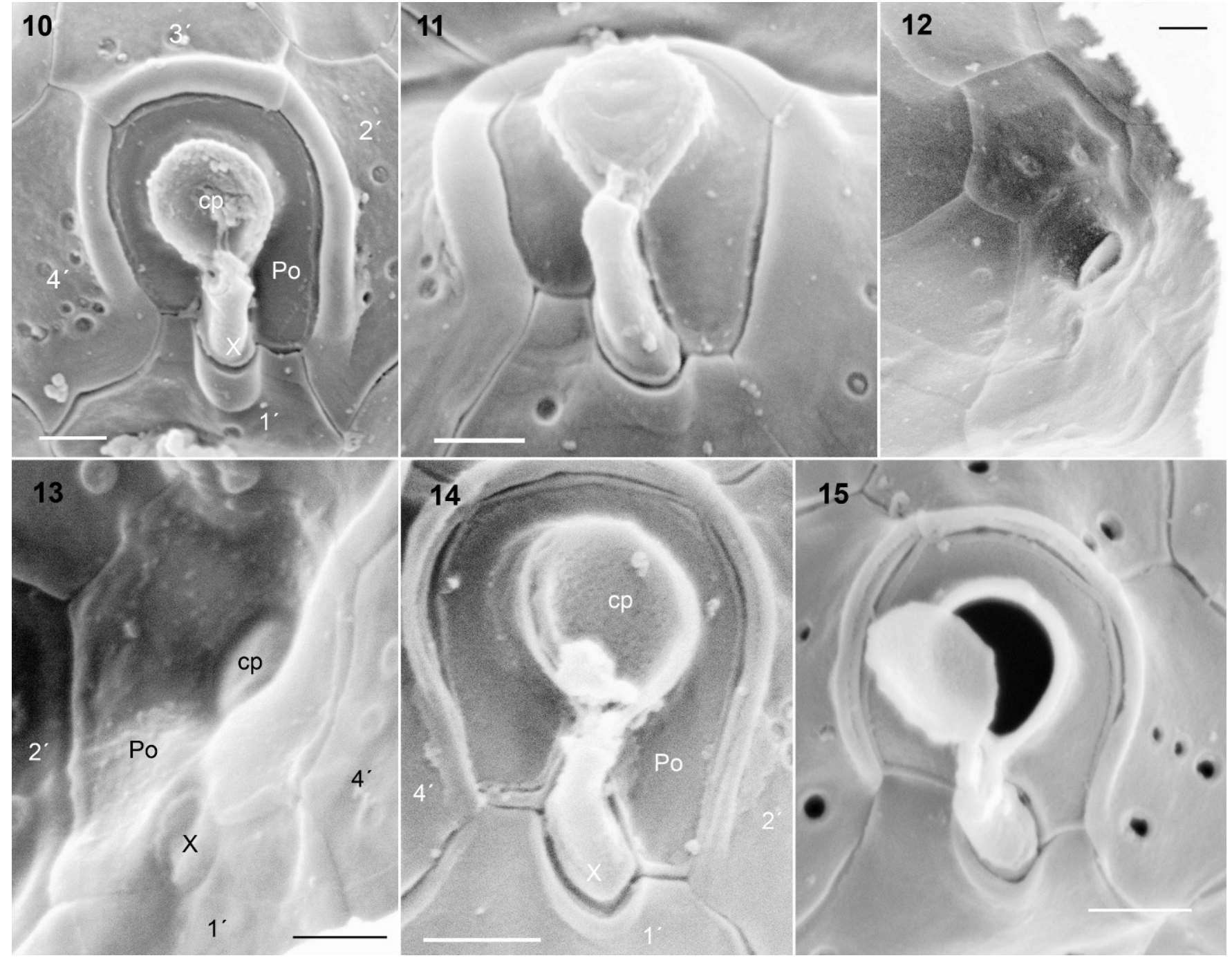

Figs 10-15. Azadinium spp. SEM pictures of different cells showing details of the apical pore complex (from 14/02/08-3, 24/06/08-3 or 02/12/ 08-1). Scale bar $=0.5 \mu \mathrm{m}$.

Figs 10, 11. Azadinium obesum viewed from outside of the cell (14/02/08-3).

Figs 12, 13. Azadinium obesum viewed from inside of the cell $(14 / 02 / 08-3)$. Po $=$ pore plate; $\mathrm{cp}=$ cover plate; $\mathrm{X}=\mathrm{X}$-plate.

Figs 14, 15. Azadinium spinosum, APC in apical view (14: 24/06/08-3, 15: 02/12/08-1). Note that in Fig. 15 the cover plate, although detached from the pore, is still connected to the finger-like protrusion of the X-plate.

\section{RESULTS}

Azadinium obesum sp. nov. Tillmann \& Elbrächter

Figs $1-8,10-13,16-33$

DIAGNOSIS: Differt de A. spinosum in absencia de spinum antapicaliter. Lamella primus praecingularis non contact lamella primus intercalaris epithecalis. Chloroplastis sine pyrenoideum apparente in microscopus lucidum. Formula tabulation: Po, cp, X, 4', 3a, 6", 6C, 5?S, 6'", 2"'"'. Longitudine circa 13-18 $\mu \mathrm{m}$, latitudine circa 10-14 $\mu \mathrm{m}$.

Differs from $A$. spinosum in the absence of an antapical spine. The first precingular plate does not touch the first epithecal intercalary plate. Chloroplast without visible pyrenoid in the light microscope. Plate tabulation: Po, cp, $\mathrm{X}, 4^{\prime}, 3 \mathrm{a}, 6^{\prime \prime}, 6 \mathrm{C}, 5 ? \mathrm{~S}, 6^{\prime \prime \prime}, 2^{\prime \prime \prime \prime}$. Cell length is about 13-18 $\mu \mathrm{m}$, cell width about $10-14 \mu \mathrm{m}$.
HOLOTYPE: SEM-stub (original stub nr. 14/2/08-3, new designation nr. CEDiT2009H4), deposited at the Senckenberg Research Institute and Natural History Museum, Centre of Excellence for Dinophyte Taxonomy, Germany.

ISOTYPE: Formalin-fixed sample (designation CEDiT2009I5), deposited at the Senckenberg Research Institute and Natural History Museum, Centre of Excellence for Dinophyte Taxonomy, Germany.

TYPE LOCALITY: $57^{\circ} 3.9^{\prime} \mathrm{N}, \quad 02^{\circ} 30.2^{\prime} \mathrm{W}$, North Sea off Scotland.

HABITAT: Marine plankton.

ETYMOLOGY: The epithet refers to the obese, corpulent appearance of the species when compared to the more slender shape of the type, A. spinosum. 

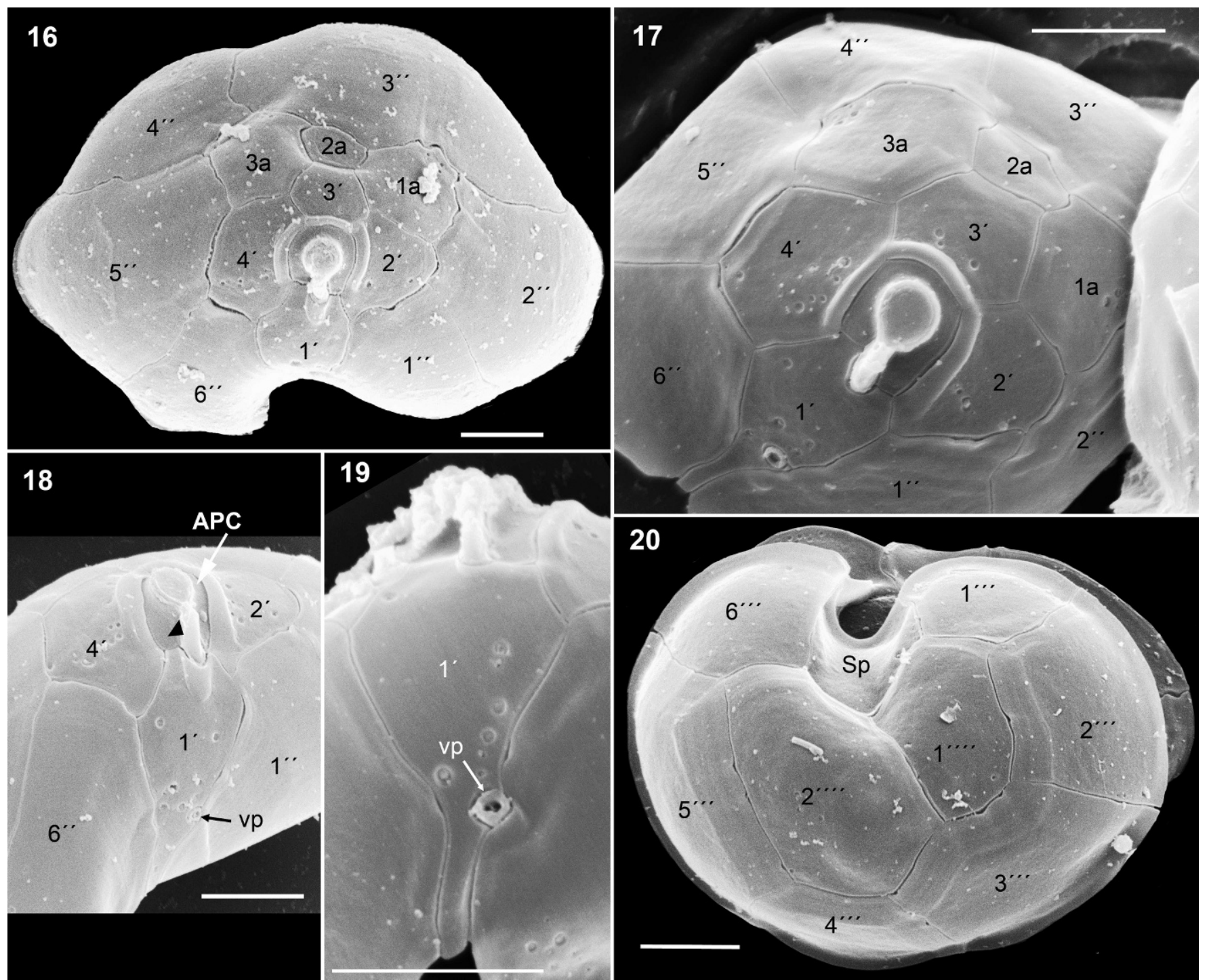

$3 a$
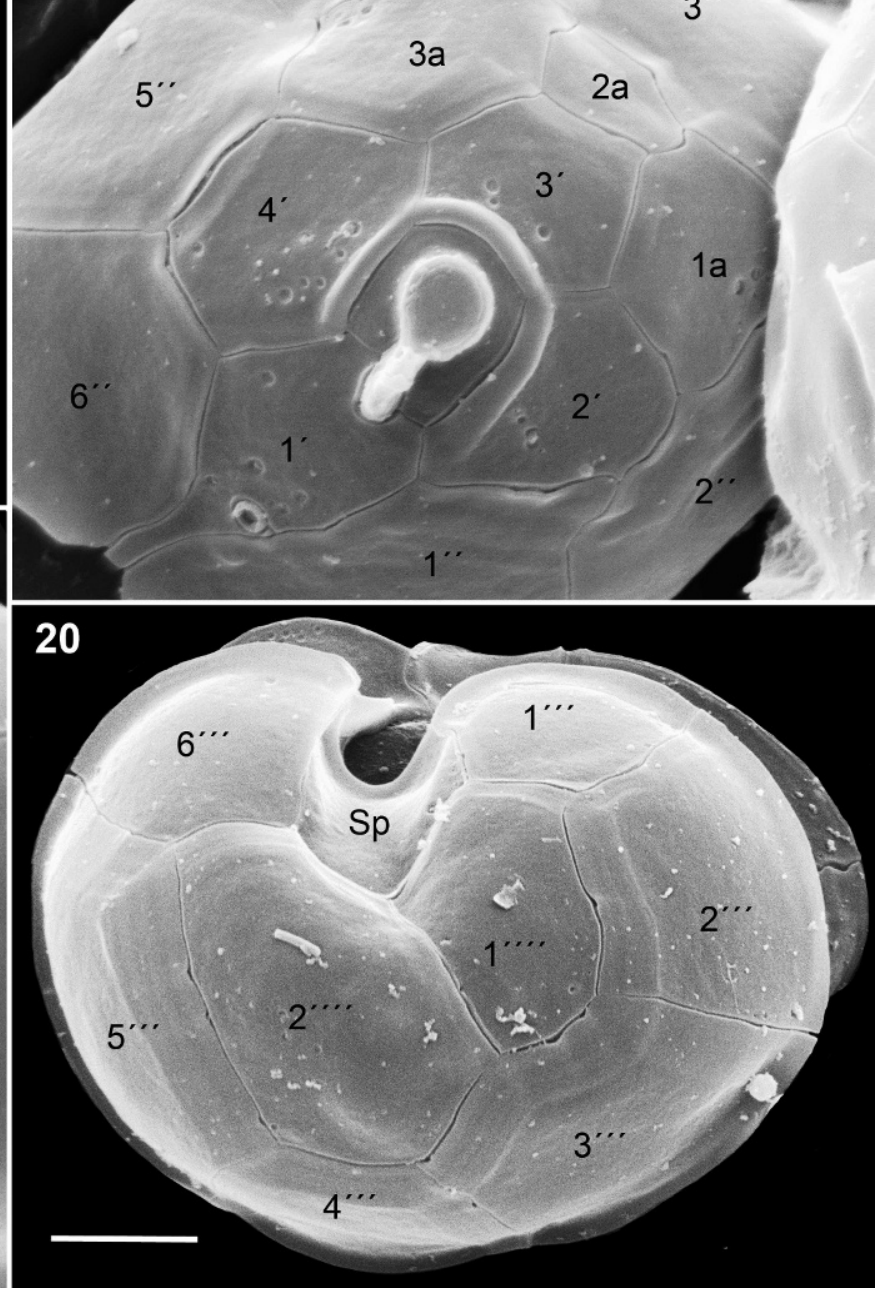

Figs 16-20. Azadinium obesum. SEM pictures (from 14/02/08-3 and 14/02/08-4) of different cells showing epithecal plates (Figs 16-19) and hypothecal plates (Fig. 20). Scale bar $=2 \mu \mathrm{m}$.

Figs 16, 17. Apical view showing the whole series of epithecal plates (14/02/08-4).

Figs 18, 19. Ventral view showing the apical pore complex (APC) with the finger-like protrusion (arrowhead) and the ventral pore (vp) $(14 / 02 / 08-3)$.

Fig. 20. Antapical view showing the whole series of hypothecal plates (14/02/08-3).

\section{Cell morphology}

Cells of A. obesum are ovoid and dorsoventrally compressed. The hemispherical episome ends with a conspicuous apical pore complex (APC) and is slightly larger than the hemispherical hyposome. The cingulum is deep and wide, roughly accounting for one-fifth of total cell length. Cells are small and range from 13.3 to $17.7 \mu \mathrm{m}$ in length and 10.0 to $14.3 \mu \mathrm{m}$ in width (median length: 15.3 , median width $11.7 \mu \mathrm{m}, n=36$; theca measurement from SEM images, Fig. 9) with a median length-to-width ratio of 1.3. The large nucleus is spherical and located in the posterior part of the cell (Fig. 4). A single chloroplast is parietally arranged and lobed and extends into both epi- and hyposome (Fig. 3). In the light microscope, no pyrenoid is visible.
Under the light microscope, living cells superficially resemble gymnodinioid dinoflagellates (Fig. 1). Azadinium obesum cells, however, possess delicate thecal plates, which can be readily seen in the light microscope (Figs 2-4). The delicate theca can be stained with calcofluor white (not shown), but due to the small size and the delicate nature of the plates, detailed analysis of the plate pattern using fluorescence microscopy proved difficult. In any case, the plate pattern resolved by SEM (Figs 16-28) was in accordance with that analysed from calcofluor-stained cells. Generally, the surface of the plates is smooth but irregularly covered by pores of different size (ranging from 0.07 to $0.14 \mu \mathrm{m}$ in diameter).

The basic thecal plate arrangement was determined as Po, cp, X, 4', 3a, 6", 6C, 5?S, 6'", 2"'" and is as drawn in Figs 23-28. The apical pore is round or slightly ellipsoid; it 

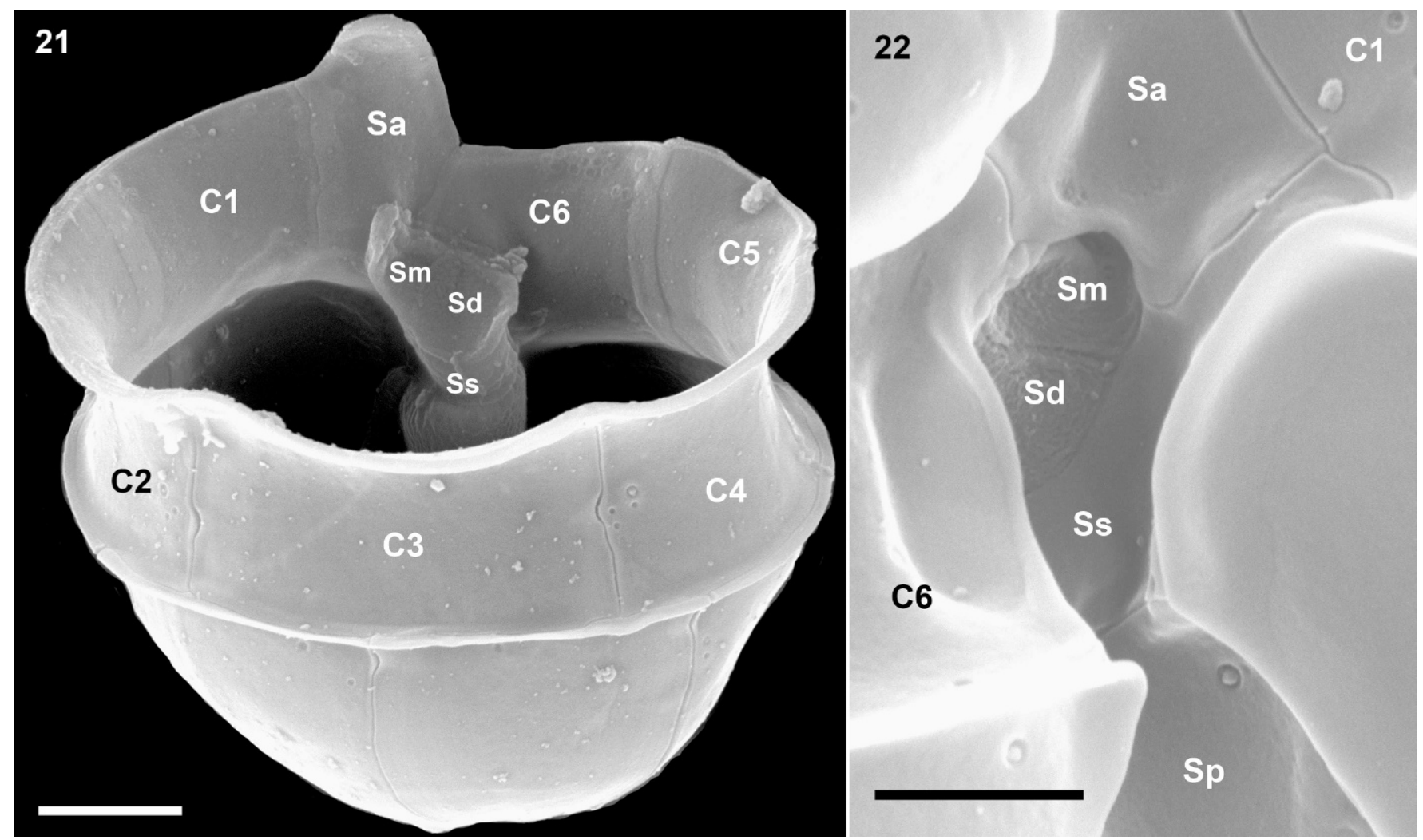

Figs 21, 22. Azadinium obesum. SEM pictures of different cells showing details of the cingulum and sulcus. Scale bar in Fig. $21=2 \mu \mathrm{m}$ and in Fig. $22=1 \mu \mathrm{m}$

Fig. 21. Hypotheca and cingulum in dorsal view. Note the internal three-dimensional structure of of sulcal plates (14/02/08-3).

Fig. 22. Detailed view of the sulcal region (14/02/08-5). Sa = anterior sulcal plate; $\mathrm{Sp}=$ posterior sulcal plate; Ss = left sulcal plate;

$\mathrm{Sm}=$ median sulcal plate; $\mathrm{Sd}=$ right sulcal plate.

is located in the centre of a pore plate and is covered by a cover plate. The pore plate is bordered by a conspicuous rim, which runs around from dorsal to both lateral sides but is lacking ventrally, where the pore plate abuts the first apical plate and the small X-plate. This latter plate roughly occupies one-third of the connection between Po and 1' and semicircularly invades the first apical plate. Generally, the Po-X-1' connection is slightly asymmetric in that the suture right from the $\mathrm{X}$-plate is located closer to the apical pore compared to the left suture (Figs 10-13). The X-plate has a very characteristic three-dimensional structure with fingerlike protrusions contacting the cover plate (Figs 10, 11). From outside it looks as if the suture of the X-plate runs through the whole pore-plate (Fig. 11) up to the rim of the apical pore. However, when seen from inside the cell, it is obvious that the X-plate is small and ovoid (Figs 12, 13). The same apical pore complex configuration has been recently discovered in $A$. spinosum (Figs 14, 15).

The apical series is composed of four plates. Plate $1^{\prime}$ is of the ortho pattern but slightly asymmetric, and the suture joining plate $6^{\prime \prime}$ is shorter than that joining plate 1 " (Figs 16-19). The lower half of plate $1^{\prime}$ is very narrow (Figs 5, 17, 19).

A ventral pore is present on the left margin of plate $1^{\prime}$ (Figs 17-19). Plates $2^{\prime}$ and $3^{\prime}$ are small. Plate $4^{\prime}$ is slightly larger and obvious in ventral view; whereas, plate $2^{\prime}$ is displaced more dorsally, causing the asymmetry of plate $1^{\prime}$. The three intercalary plates are arranged more or less symmetrically on the dorsal side of the epitheca. All intercalary plates are quite small with the four-sided plate 2a being the smallest (Figs 16, 17). The six precingular plates are of comparable size. Both ventral precingular plates $\left(1^{\prime \prime}, 6^{\prime \prime}\right)$ are five-sided and only in contact with three apical plates but not with an intercalary plate (Figs 16, 17). The hypotheca has a plate arrangement consisting of six postcingular and two antapical plates (Fig. 20). All postcingular plates are of comparable size, but the four-sided plate $4^{\prime \prime \prime}$ is the smallest; whereas, plate $5^{\prime \prime \prime}$ (also four-sided) is the largest. The two antapical plates are of markedly different size, with plate $1^{\prime \prime \prime \prime}$ slightly displaced to the left.

The cingulum is wide, descending, displaced by about half of its width, and is composed of six plates of almost equal size (Fig. 21). Narrow cingular lists are present, particularly on the posterior cingulum fringe. In addition, a convexity of the sixth cingular plate partly covers the sulcal area and the flagellar pore region (Figs 5, 22). The plate pattern of the deeply concave sulcus is difficult to resolve and interpret. The large anterior sulcal plate (Sa) partly invades the epitheca; whereas, the large posterior sulcal plate ( $\mathrm{Sp}$ ) extends twothirds of the way from the cingulum to the antapex. A left sulcal plate $\mathrm{Ss}$ is located anterior to $\mathrm{Sp}$ and abuts plates $1^{\prime \prime \prime}$, $\mathrm{C} 1, \mathrm{Sa}, \mathrm{Sd}, \mathrm{Sm}$ and $\mathrm{Sp}$. The right sulcal plate $\mathrm{Sd}$ abuts sulcal plates Ss and $\mathrm{Sm}$ as well as cingular plate C6. The median sulcal plate $\mathrm{Sm}$ contacts sulcal plates $\mathrm{Sa}$, Ss and $\mathrm{Sd}$ (Fig. 22). These plates apparently have a complicated three-dimensional morphology, with large flanges invading into the 


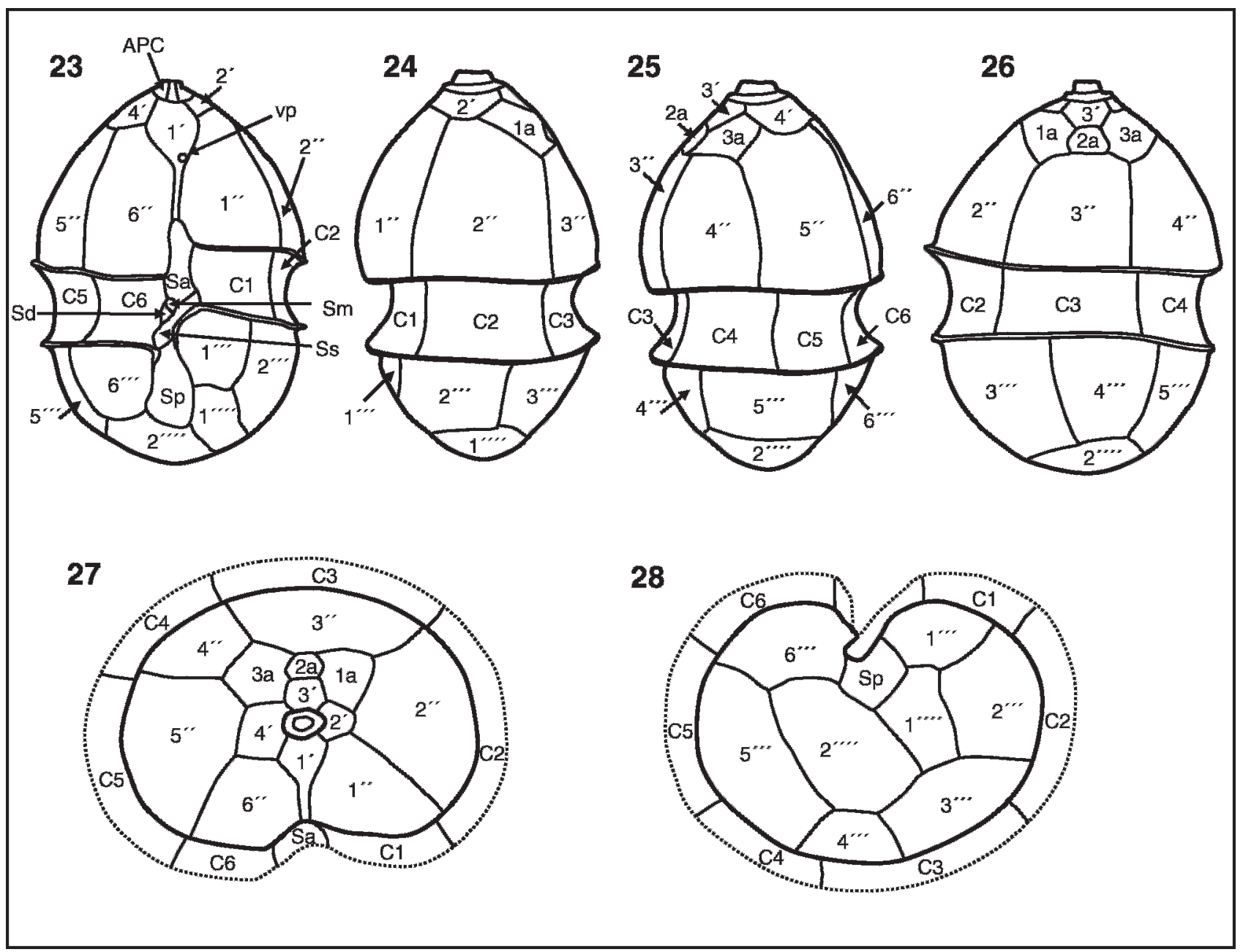

Figs 23-28. Azadinium obesum. Diagrammatic illustration of thecal plates.

Fig. 23. Ventral view. APC = apical pore complex; Sa, Sd, Sm, Sp, Ss = sulcal plates; vp = ventral pore).

Fig. 24. Left side.

Fig. 25. Right side.

Fig. 26. Dorsal view.

Fig. 27. Apical view.

Fig. 28. Antapical view.

hypotheca (see Fig. 21). We do not exclude the possibility that there are more tiny sulcal plates, but these could not be resolved by calcofluor-staining and epifluorescence microscopy or SEM. Dissection with hypochlorite also did not resolve further platelets.

The plate pattern shown in Figs 23-28 is the standard basic pattern. Several variations were, however, observed (see Figs 29-33). Most variations can be interpreted as extra divisions of pre-existing plates to yield additional plates, a modification that has been designated as a 'complexum modification' by Lefevre (1932). Complexum modifications were commonly observed on the epitheca, specifically by division of apical plates $3^{\prime}$ and/or 2 a and/or $3^{\prime \prime}$ or, more rarely, by division of plates $2^{\prime}$ or $4^{\prime}$. Among 46 specimens for which a complete epithecal view was available, more than half $(57 \%)$ showed a complexum modification (Table 2). For a large majority of these 'modified' specimens, more than one epithecal plate was doubled with a joint doubling of plate $2 \mathrm{a}$ and $3^{\prime}$ being most common (Table 2).

Another variation refers to the relative position the small intercalary plate $2 \mathrm{a}$. The plate $2 \mathrm{a}$ is 'normally' four-sided and in contact with plates $3^{\prime}$, 1a, 3a, and 3". However, as depicted in Fig. 29, plate 2a may also be slightly distorted and in contact with plate $4 "$, which was observed for $8(31 \%)$ among 26 individuals with one 2a-plate, for which these plates were visible. For all specimens with plate $2 \mathrm{a}$ doubled, the right plate 2 a was always in contact with plate $4^{\prime \prime}$.

\section{Pigment composition}

Pigment analysis by high-performance liquid chromatography with diode array detection revealed that $A$. obesum contained a pigment pattern (Fig. 34) that is typical for most photosynthetic dinoflagellates, with chl $\mathrm{c} 2$ as the major accessory chlorophyll to chl a and peridinin as the 

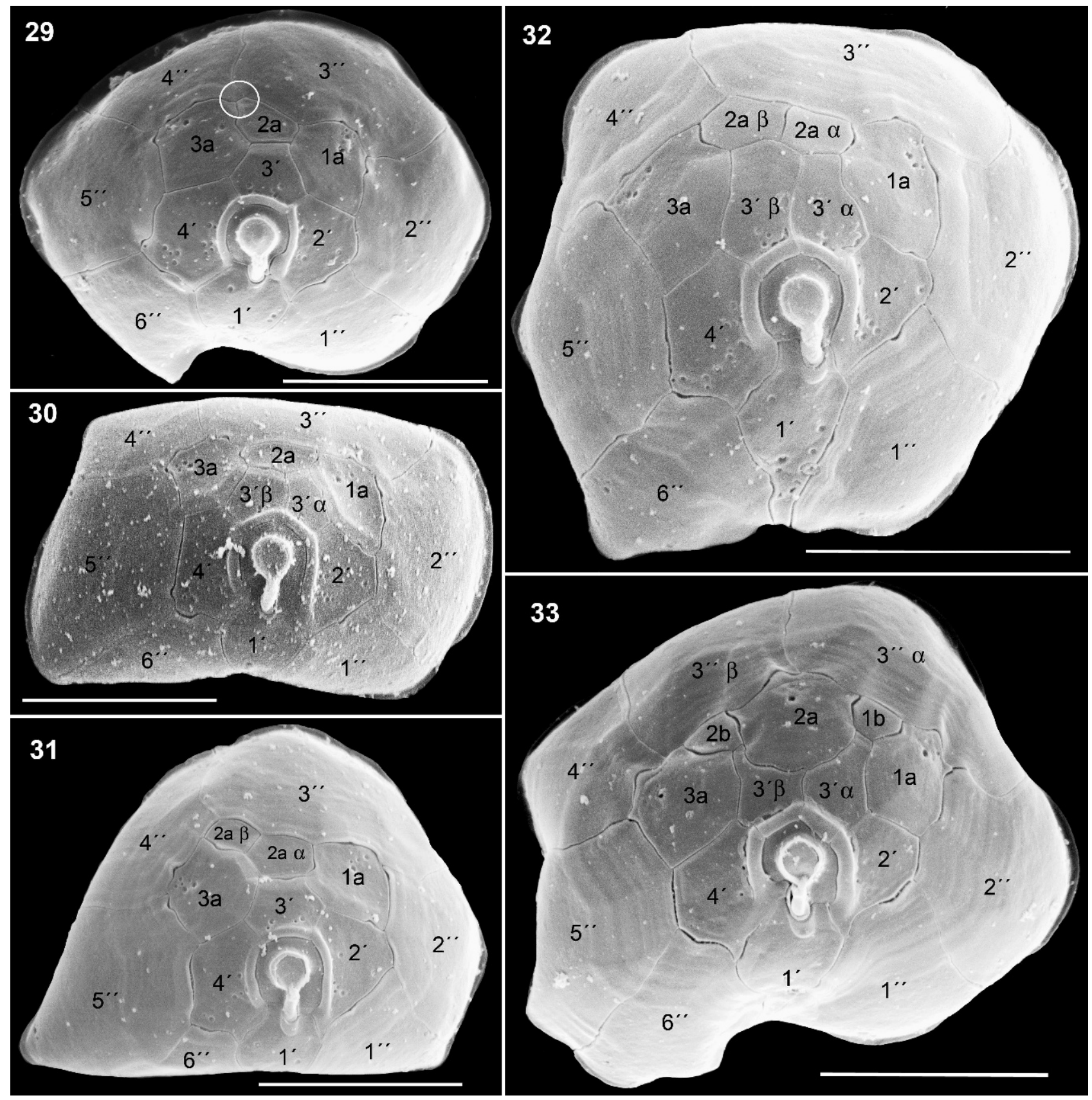

Figs 29-33. Azadinium obesum. Variations in plate pattern observed in culture (SEM pictures from 14/02/08-4 and 14/02/08-3). The designation of the putatively subdivided thecal plates is directly adopted from Morrill \& Loeblich (1981). Scale bar $=5 \mu \mathrm{m}$.

Fig. 29. Epitheca in apical view showing the small intercalary plate $2 a$ in contact to plate 4 " (white circle) (14/02/08-4).

Fig. 30. Epitheca in apical view showing a doubling of the plate $3^{\prime}(14 / 02 / 08-4)$.

Fig. 31. Epitheca in apical view showing a doubling of the small intercalary plate 2 a $(14 / 02 / 08-4)$

Fig. 32. Epitheca in apical view showing a doubling of both plates $3^{\prime}$ and 2 a (14/02/08-4).

Fig. 33. Epitheca in apical view (14/02/08-3). In this specimen, a number of additional plates can be observed. These are interpreted as a result of a splitting of the plates plate $3^{\prime}$ and $3^{\prime \prime}$ and (b) formation of an additional set of two small intercalary plates (herein termed $1 \mathrm{~b}$ and $2 \mathrm{~b}$ ). With this interpretation, plate $2 \mathrm{a}$ is considerably enlarged compared to the normal scheme.

major carotenoid. In addition, the carotenoids diadinoxanthin, dinoxanthin, and prasinoxanthin were identified.

\section{Azaspiracid analysis}

We were unable to detect any azaspiracids AZA-1 to AZA12 in the cultured $2 \mathrm{E} 10$ strain of $A$. obesum by LC-MS/MS. Standards were only available for AZA-1, AZA-2 and
AZA-3, but mass transitions for the other congeners were used according to James et al. (2003). Two peaks in the ion trace $m / z 844>826($ AZA-4 and AZA-5) were recorded at retention times of 12.1 and $13.3 \mathrm{~min}$, respectively, but product ion spectra of these two peaks showed completely different fragments than those expected of AZA-4 and AZA-5 (Lehane et al. 2004), such that the presence of AZA1 to AZA-12 can be excluded. The limit of detection (signal- 


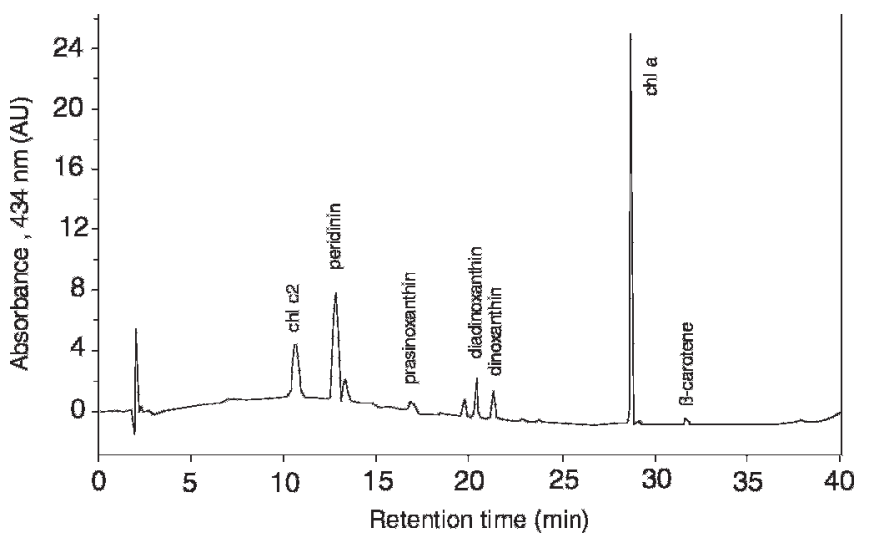

Fig. 34. High-performace liquid chromatography chromatogram of photosynthetic pigments (detection at $434 \mathrm{~nm}$ ) of Azadinium obesum. Only pigments corresponding to known standards are named. Retention time $(\min )$ on the $\mathrm{x}$-axis; absorbance $(\mathrm{AU}=$ arbitrary units) on the y-axis.

to-noise ratio $=5$ ) was determined as $350 \mathrm{fg}$ on-column (AZA-1 equivalents), which, for our measurement, would be equivalent to a detectable cell quota of $3.6 \mathrm{ag} \mathrm{cell}^{-1}$. The toxic relative $A$. spinosum in turn has a AZA cell quota of three to four orders of magnitude higher than this detection limit (5-40 fg cell ${ }^{-1}$ ) (Krock et al. 2009).

\section{Molecular analysis}

Phylogenetic analysis of the generated sequences from $A$. obesum are illustrated in Figs 35 and 36 as ML dendrograms for the ITS and COI sequences, respectively. In both analyses, $A$. obesum and $A$. spinosum form a well bootstrapsupported sister group to the Gymnodiniales, Peridiniales and Prorocentrales in the case of ITS and additionally with members of the gonyaulacales in the COI phylogeny. The phylogenies of the $18 \mathrm{~S}$ rRNA and D1D2 region of the $28 \mathrm{~S}$ rRNA showed the same results for the Azadinium species and were also consistent with our previous results (data not shown). While we discovered only four base substitutions in the 18S rRNA sequences between the two Azadinium taxa, 22 differences were exhibited in the 28S rRNA sequences, 16 for ITS and none for the COI gene (see Table 3 ).

\section{DISCUSSION}

\section{Morphology}

With the Kofoid tabulation Po, cp, X, 4', 3a, 6", 6C, 5?S, $6^{\prime \prime \prime}, 2^{\prime \prime \prime \prime}$, this taxon exactly fits into the newly described dinoflagellate genus Azadinium within the subclass Peridiniphycidae (Tillmann et al. 2009). Unfortunately, comparative morphological analysis of this taxon with the type species of the genus, $A$. spinosum, does not clarify taxonomic affinities with respect to the Gonayaulacales or Peridiniales or other higher-level taxonomic entities. Nevertheless, under the light microscope it can be separated from $A$. spinosum by the consistent absence of an antapical spine, which is only very rarely absent in cells from cultures of A. spinosum and hence serves as a primary species descriptor. Also different from A. spinosum is the lack of a stalked pyrenoid in $A$. obesum. In general, A. obesum also differs slightly but significantly (see Fig. 9) in size (slightly longer and wider) and in shape (not so elongated) from $A$. spinosum; however, there is overlap in the size range (Fig. 9). In any case, the two species are clearly separated by their different tabulation. The first precingular plate of A. obesum does not touch the first epithecal intercalary plate as in $A$. spinosum. For $A$. obesum, the first precingular plate is four-sided, touching only plates $1^{\prime}, 2^{\prime}, 2^{\prime \prime}$ and the cingulum; whereas, in $A$. spinosum the first precingular plate is five-sided, touching plates $1^{\prime}, 2^{\prime}, 1 \mathrm{a}, 2^{\prime \prime}$ and the cingulum. In addition, the shape of the first apical plate in A. obesum is also distinctive; the lower half of the plate is very narrow, tongue-like, and, in consequence, the sutures between plate 1' and both precingular plates 1" and 6" are very close together (Figs 5, 17, 19), running more or less parallel; whereas, these diverge in $A$. spinosum.

We conclude based upon cultured material that the morphotype of $A$. obesum is stable albeit with some variations and is readily differentiated from $A$. spinosum in critical LM and SEM analysis, thereby warranting the separation of $A$. obesum on the species level from the type of the genus, A. spinosum. The degree of plate pattern variability for $A$. obesum (Table 2, Figs 29-33) is comparable to the variability described for a culture of the type of the genus, A. spinosum (Tillmann et al. 2009). Variability was mainly caused by subdivisions of plates in the dorsal area of the epitheca; whereas, the hypothecal tabulation was more stable. We did consider the possibility of 'morphological drift' in culture, but this does not appear to be manifest even after more than $1 \mathrm{yr}$ since isolation. Aberrant morphotypes (loss of chain formation, rounding of cell margins, changes in cell size, distortion of thecal plates or sutures) is also common in dinoflagellates undergoing life cycle transitions (gamete or planozygote formation), but there was no evidence of sexual reproduction or cyst formation in our culture. The apparent healthiness and rapid growth of the cultures and the relatively short time since isolation argues that this represents natural variation among vegetative cells rather than induced artefacts or alternative life cycle stages. However, SEM studies on field samples are needed to clarify this issue.

Tillmann et al. (2009) mentioned that Gonyaulax parva Ramsfjell (Ramsfjell 1959) may belong to the genus Azadinium as it has the same tabulation pattern; although, the cingular and sulcal plates are so far unknown in this species. Gonyaulax parva differs from $A$. obesum by the configuration of the epithecal plates: $2^{\prime}$ and 4 ' are equalsized and very small, as are the three apical intercalary plates, and plate $2 \mathrm{a}$ is five-sided in G. parva. In A. obesum, plate $2^{\prime}$ is displaced dorsally and smaller than plate $4^{\prime}$, plate $2 \mathrm{a}$ is four-sided and by far the smallest of the three apical intercalary plates. Therefore, we regard $A$. obesum as distinct on species level from $G$. parva, for which the cingular and sulcal plates are unknown. Schiller (1935) invalidly described Gonyaulax gracilis Schiller without depicting the tabulation. In shape, this dinoflagellate has some resemblance to $A$. obesum, although $G$. gracilis is much more elongated. The dinoflagellate depicted as $G$. 


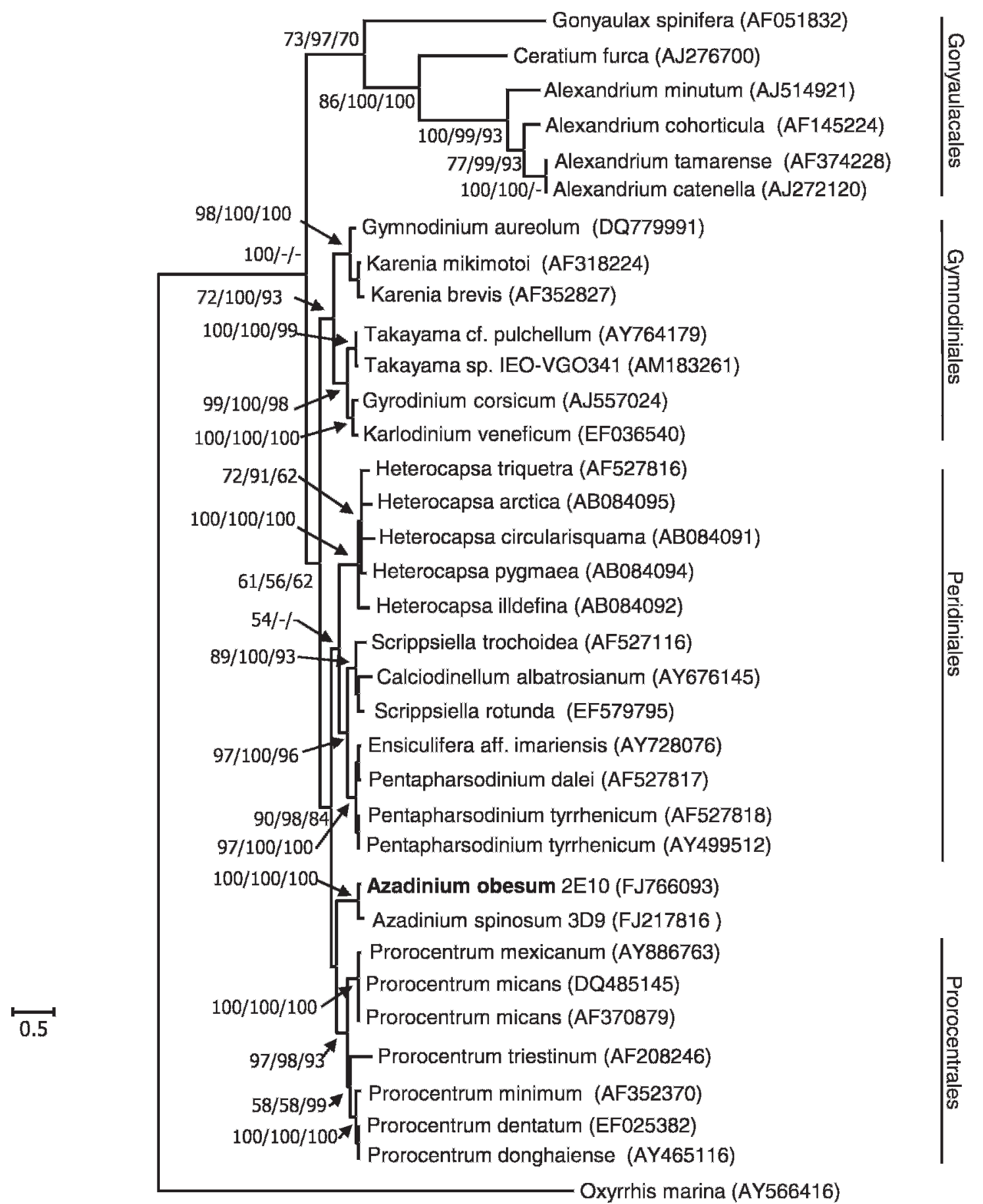

Fig. 35. Maximum likelihood (ML) phylogenetic tree of the dinoflagellates inferred from the internal transcript spacer (ITS) from the rDNA operon. Oxyrrhis marina was used as out-group. Bootstrap values are given at the nodes in the following order: maximum likelihood (ML), neighbour joining (NJ) and maximum parsimony (MP).

gracilis from the St. Lawrence Gulf in the western Atlantic (Bérard-Therriault et al. 1999) has an antapical spine and therefore in this sense resembles $A$. spinosum but not $A$. obesum as described here.

The APC was not fully resolved in the type of the genus, $A$. spinosum, but we succeeded in analysing it in the present study on $A$. obesum. Subsequent investigations of $\mathrm{A}$. spinosum showed the same configuration (Figs 14, 15). The APC comprises - as typical for the Peridiniales - a pore plate with a cover plate and the X-plate, which is very small in both Azadinium species. In contrast, however, to most species of the Peridiniales, such as Protoperidinium Bergh, Scrippsiella Balech \& Loeblich, Pentapharsodinium Indelicato and Loeblich III, Ensiculifera Balech and those of the Diplopsalis group, the X-plate does not separate completely the first apical plate $\left(1^{\prime}\right)$ from the pore plate but invades plate 1 ', giving broad contact of plate 1 ' to the pore plate, each right and left, respectively from the X-plate (Figs 10, 


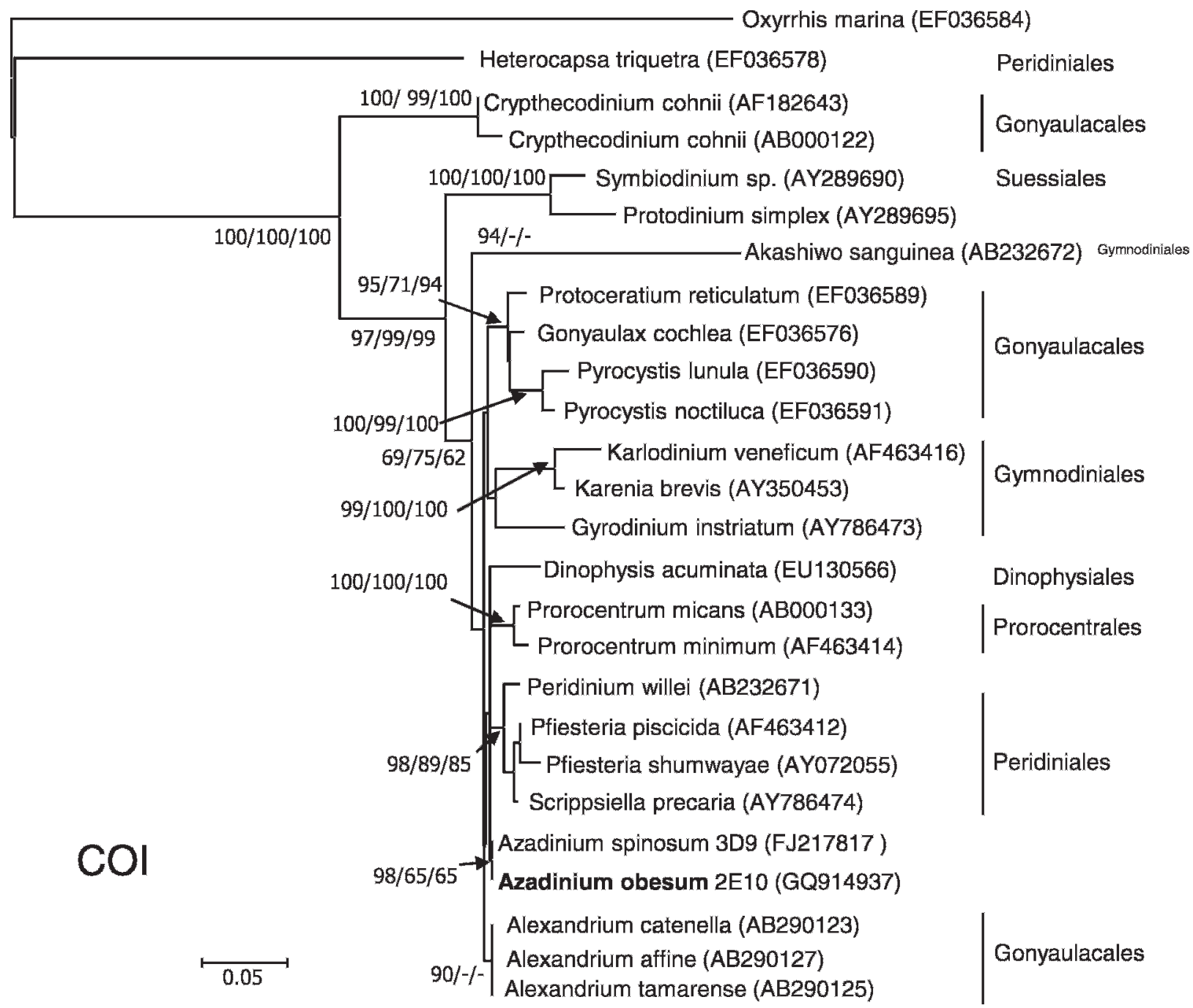

Fig. 36. Maximum likelihood (ML) phylogenetic tree of the dinoflagellates inferred from cytochrome c oxidase (COI). Oxyrrhis marina was used as out-group. Bootstrap values are given at the nodes in the following order: maximum likelihood (ML), neighbour joining (NJ) and maximum parsimony (MP).

11). Direct contact of plate $1^{\prime}$ to the pore plate is characteristic for the Gonyaulacales, for which the X-plate is missing, but this is unusual in Peridiniales. The only examples we know of are represented in the Heterocapsa Stein-Cachonina Loeblich species complex. In these species,

Table 2. Azadinium obesum, quantification of epithecal plate pattern variation.

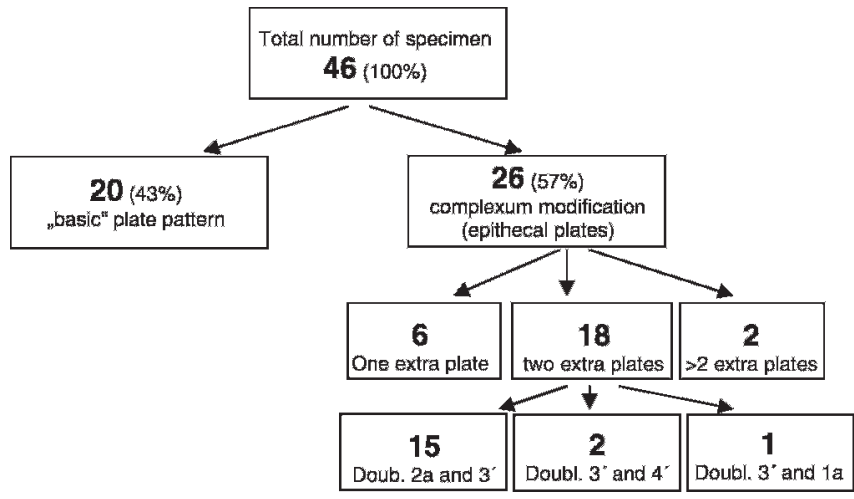

the X-plate is displaced to the right side, consequently allowing direct contact of plate $1^{\prime}$ and the pore plate at the left side from the X-plate, as clearly depicted by, e.g., Dodge and Hermes (1981) (their figs 4 and 15D) or by Steidinger and Tangen in Tomas (1997) (their plate 6, fig. B).

\section{Phylogeny}

The sequence and phylogenetic analysis elucidates and supports the separation of $A$. obesum from $A$. spinosum as a new species and further validates the recently erected genus Azadinium with its unresolved position within the dinoflagellate groups of Peridiniales, Gonyaulacales, Prorocentrales and Gymnodiniales. The general topologies of the ITS and COI dendrograms were similar to those from Tillmann et al. (2009), with the new sequences of $A$. obesum grouping together with $A$. spinosum. We could not further resolve the position of the Azadinium genus within the dinoflagellate phylogeny, but our analysis demonstrated the identity of the new taxon as the second described species of this genus. This Azadinium clade is well supported with high bootstrap values. The sequence differences between the two 
Table 3. Pairwise sequence comparison among Azadinium obesum and Azadinium spinosum.

\begin{tabular}{lcccc}
\hline \multicolumn{1}{c}{ Gene } & $\begin{array}{c}\text { Base } \\
\text { substitutions }\end{array}$ & Transitions & Transversions & $\begin{array}{c}\text { Insertion/ } \\
\text { deletion }\end{array}$ \\
\hline 18S rRNA & 4 & 3 & 2 & 0 \\
28S rRNA & 22 & 15 & 7 & 0 \\
ITS rRNA & 16 & 11 & 5 & 3 \\
COI & 0 & 0 & 0 & 2 \\
\hline
\end{tabular}

Azadinium species encourage the separation (Table 3). A similar number of nucleotide differences were found among species of dinoflagellates, such as in the genus Alexandrium (John et al. 2003; Montresor et al. 2004), and in diatoms (stramelopiles) within the hypervariable D1D2 region of the 28S rDNA gene (Beszteri et al. 2007). The relative lack of base substitutions in the COI gene, with variation restricted only to deletions/insertions, is consistent with our findings among Alexandrium species and might reflect the slower rate of gene evolution in the COI gene relative to the sequences from the ribosomal cistron.

\section{Azaspiracid toxins}

This new taxon is assigned to a dinoflagellate genus defined by a generic descriptor from the type species as reflecting the capacity to produce AZA toxins. However, in contrast to the 3D9 strain of the type species, A. spinosum, our strain of $A$. obesum obviously produces neither AZA-1 and/or AZA-2 in significant amounts nor any toxin of the AZA-3 to AZA-12 group. However, Rehman et al. (2008) have shown that there are many more structural AZA variants, such that to date the number of described analogues has increased to 32. Due to the fact that the AZA-producing organism was unknown until recently, all AZA variants have been isolated from shellfish. Most of these compounds are hydroxylated or carboxylated derivatives and believed to be shellfish metabolites and, therefore, not likely to be found in phytoplankton. On the other hand it cannot be excluded that species of the genus Azadinium produce other AZA-related compounds, which have not been detected so far, possibly because of metabolic activity of shellfish. Further research is needed to clarify this issue.

In general, with only one strain per species currently available, we have to be careful in interpreting any taxonomic or evolutionary significance into the observation of AZA production in $A$. spinosum and lack of AZA in $A$. obesum. This is because toxigenicity and secondary metabolite production in general has proven to be a highly variable phenotypic characteristic at the genus, species and even population level among dinoflagellates (Cembella 2003). In any case, the existence of nontoxic species/strains of the genus Azadinium, which co-occur in the same water mass, complicates all attempts to identify/quantify the source organism of AZAs by routine monitoring programmes using light microscopy. Although these species differ in the light microscope, diagnostic features are either difficult to see (existence of the tiny antapical spine in $A$. spinosum) or easily masked in fixed samples (presence of pyrenoid). Thus, both FISH and qPCR probes able to discriminate $A$. spinosum from $A$. obesum are currently being designed and developed in order to routinely quantitatively detect and discriminate the toxin-producing species $A$. spinosum in field samples. But, again, it is premature to conclude that the capacity for AZA biosynthesis is a fully diagnostic criterion for Azadinium species this has often proven not to be the case for toxin production in other dinoflagellates (reviewed in Wright and Cembella 1998). We, nevertheless, fully expect more intraspecific and intrageneric representatives of this recently discovered genus (Tillmann et al. 2009; Krock et al. 2009) to emerge when more surveys are conducted, particularly in the North Sea and North Atlantic, where azaspiracids have been most often detected in plankton and shellfish.

\section{REFERENCES}

Bérard-Therriault L., Poulin M. \& Bossé L. 1999. Guide d'identification du phytoplancton marin de l'estuaire et du golfe de Saint-Laurent incluant également certaines protozoaires. Publication spéciale canadienne des sciences halieutiques et aquatiques 128: 1-387.

Beszteri B., John U. \& Medlin L.K. 2007. An assessment of cryptic genetic diversity within the Cyclotella meneghiniana species complex (Bacillariophyta) based on nuclear and plastid genes, and amplified fragment length polymorphisms. European Journal of Phycology 42: 47-60.

Cembella A.D. 2003. Chemical ecology of eukaryotic microalgae in marine ecosystems. Phycologia 42: 420-447.

Dahl E., Lindahl O., PaAsche E. \& Throndsen J. 1989. The Chrysochromulina polylepis bloom in Scandinavian waters during spring 1988. In: Novel phytoplankton blooms: causes and impacts of recurrent brown tides and other unusual blooms (Ed. by E.M. Cosper, V.M. Bricelj \& E.J. Carpenter), pp. 383-405. SpringerVerlag, Berlin.

Dodge J.D. \& Hermes H.B. 1981. A scanning electron microscopical study of the apical pores of marine dinoflagellates (Dinophyceae). Phycologia 20: 424430.

Felsenstein J. 1985. Confidence limits on phylogenies: an approach using the bootstrap. Evolution 39: 783-791.

Fensome R.A., Taylor F.J.R., Norris G., Sarjeant W.A.S., Wharton D.I. \& Williams G.L. 1993. A classification of living and fossil dinoflagellates. Micropaleontology, Special Publication 7: $1-351$.

Fritz L. \& Triemer R.E. 1985. A rapid simple technique utilizing Calcofluor white M2R for the visualization of dinoflagellate thecal plates. Journal of Phycology 21: 662-664.

Guindon S. \& Gascuel O. 2003. A simple, fast, and accurate algorithm to estimate large phylogenies by maximum likelihood. Systematic Biology 52: 696-704.

Ito E., Satake M., Ofuji K., Higashi M., Harigaya K., McMahon T. \& Yasumoto T. 2002. Chronic effects in mice caused by oral administration of sublethal doses of azaspirazid, a new marine toxin isolated from mussels. Toxicon 40: 193-203.

James K.J., Furey A., Lehane M., Ramstad H., Aune T., HovgaArd P., Morris P., Higman W., Satake M. \& YAsumoto T. 2002. First evidence of an extensive northern European distribution of azaspirazid poisoning (AZP) toxins in shellfish. Toxicon 40: 909-915.

James K.J., Moroney C., Roden C., Satake M., Yasumoto T., LEHANE M. \& FuREY A. 2003. Ubiquitous 'benign' alga emerges as the cause of shellfish contamination responsible for the human toxic syndrome, azaspiracid poisoning. Toxicon 41: 145-154.

John U., Cembella A.D., Hummert C., Elbrächter M., Groben R. \& Medlin L. 2003. Discrimination of the toxigenic dinoflagellates Alexandrium tamarense and $A$. ostenfeldii in cooccurring natural populations from Scottish coastal waters. European Journal of Phycology 38: 25-40.

Keller M.D., Selvin R.C., Claus W. \& Guillard R.R.L. 1987. Media for the culture of oceanic ultraphytoplankton. Journal of Phycology 23: 633-638. 
Kofold C.A. 1909. On Peridinium steini Jörgensen, with a note on the nomenclature of the skeleton of the Peridinidae. Archiv für Protistenkunde 16: 25-47.

Krock B., Tillmann U., John U. \& Cembella A.D. 2008. LC MS/MS on board ship - tandem mass spectrometry in the search for phycotoxins and novel toxigenic plankton from the North Sea. Analytical and Bioanalytical Chemistry 392: 797-803.

Krock B., Tillmann U., John U. \& Cembella A.D. 2009. Characterization of azaspiracids in plankton size-fractions and isolation of an azaspiracid-producing dinoflagellate from the North Sea. Harmful Algae 8: 254-263.

LefeVre M. 1932. Monographie des especes d'eau douce du genre Peridinium. Archives de Botanique 2: 1-208.

Lehane M., SÁez M.J.F., Magdalena A.B., Cañás I.R., Sierra M.D., Hamilton B., Furey A. \& James K.J. 2004. Liquid chromatography-multiple tandem mass spectrometry for the determination of ten azaspiracids, including hydroxyl analogues in shellfish. Journal of Chromatography A 1024: 63-70.

Magdalena A.B., Lehane M., Krys S., Fernandez M.L., Furey A. \& JAMES K.J. 2003. The first identification of azaspiracids in shellfish from France and Spain. Toxicon 42: 105-108.

MCMAhon T. \& Silke J. 1996. West coast of Ireland; winter toxicity of unknown aetiology in mussels. Harmful Algae News 14: 2.

Montresor M., John U., Beran A. \& Medlin L.K. 2004. Alexandrium tamutum sp. nov. (Dinophyceae): a new nontoxic species in the genus Alexandrium. Journal of Phycology 40 $398-411$.

Morrill L.C. \& Loeblich A.R. III 1981. A survey for body scales in dinoflagellates and a revision of Cachonina and Heterocapsa (Pyrrhophyta). Journal of Plankton Research 3: 53-65.

Posada D. \& CRANDAll K.A. 1998. Modeltest: testing the model of DNA substitution. Bioinformatics 14: 817-818.

PosadA D. \& BuCKLey T.R. 2004. Model selection and model averaging in phylogenetics: advantages of the AIC and Bayesian approaches over likelihood ratio tests. Systematic Biology 53: 793-808.

RAMSFJELL E. 1959. Two new phytoplankton species from the Norwegian Sea, the diatom Coscinosira poroseriata, and the dinoflagellate Gonyaulax parva. Nytt Magasin for Botanikk 7: $175-177$.

Rehmann N., Hess P. \& Quilliam M.A. 2008. Discovery of new analogs of the marine biotoxin azaspirazid in blue mussels Mytilus edulis by ultra-performance liquid chromatrography/ tandem mass spectrometry. Rapid Communications in Mass Spectrometry 22: 549-558.
Satake M., Ofuji K., James K., Furey A. \& Yasumoto T. 1998. New toxic events caused by Irish mussels. In: Harmful algae (Ed. by B. Reguera, J. Blanco, M.L. Fernandez \& T. Wyatt), pp. 468-469. Xunta de Galicia and Interantional Oceanographic Commission of UNESCO, Santiago de Compostela.

SCHILlER J. 1935. Dinoflagellatae (Peridineae) in monographischer Behandlung. In: Dr. L. Rabenhorst's Kryptogamen-Flora von Deutschland, Österreich und der Schweiz (Ed. by L. Rabenhorst), Leipzig, Germany, E. Kummer, pp. 161-320.

Taleb H., Vale P., Amanhir R., Benhadouch A., Sagou R. \& CHAFIK A. 2006. First detection of azaspirazids in mussels in north west Africa. Journal of Shellfish Research 25: 1067-1070.

Thompson J.D., Gibson T.J., Plewniak F., Jeanmougin F. \& Higgins D.G. 1997. The ClustalX windows interface: flexible strategies for multiple sequence alignment aided by quality analysis tools. Nucleic Acids Research 25: 4876-4882.

Tillmann U., Elbrächter M., Krock B., John U. \& Cembella A. 2009. Azadinium spinosum gen. et sp. nov. (Dinophyceae) identified as a primary producer of azaspiracid toxins. European Journal of Phycology 44: 63-79.

Tomas C.R. [Ed] 1997. Identifying marine phytoplankton. Academic Press, San Diego, 858 pp.

Twiner M.J., Rehmann N., Hess P. \& Doucette G.J. 2008. Azaspiracid shellfish poisoning: a review on the chemistry, ecology, and toxicology with emphasis on human health impacts. Marine Drugs 6: 39-72.

Vale C., Botelho M.J., Rodrigues S.M., Gomes S.S. \& de M SAmpayo M.A. 2008. Two decades of marine biotoxin monitoring in bivalves from Portugal (1986-2006): a review of exposure assessment. Harmful Algae 7: 11-25.

Whelan S. \& Goldman N. 2001. A general empirical model of protein evolution derived from multiple protein families using a maximum likelihood approach. Molecular Biology and Evolution 18: 691-699.

Wright J.L.C. \& Cembella A.D. 1998. Ecophysiology and biosynthesis of polyether marine biotoxins. In: Physiological ecology of harmful algal blooms (Ed. by D.M. Anderson, A.D. Cembella \& G.M. Hallegraeff), pp. 427-451. Springer-Verlag, Berlin.

Zhang H., Bhattacharya D. \& LiN S. 2005. Phylogeny of dinoflagellates on mitochondrial cytochrome $\mathrm{b}$ and nuclear small rDNA. Journal of Phycology 41: 411-420.

Received 23 April 2009; accepted 14 September 2009 Associate editor: Jacob Larsen 


\section{Corrigendum}

Correction to paper by Urban Tillmann, Malte Elbrächter, Uwe John, Bernd Krock and Allan Cembella (2010). Azadinium obesum (Dinophyceae), a new nontoxic species in the genus that can produce azaspiracid toxins. Phycologia 49 (2): 169-182.

Due to a printer's error, Figs 30-33 were printed with missing information. The correct version is reprinted here.
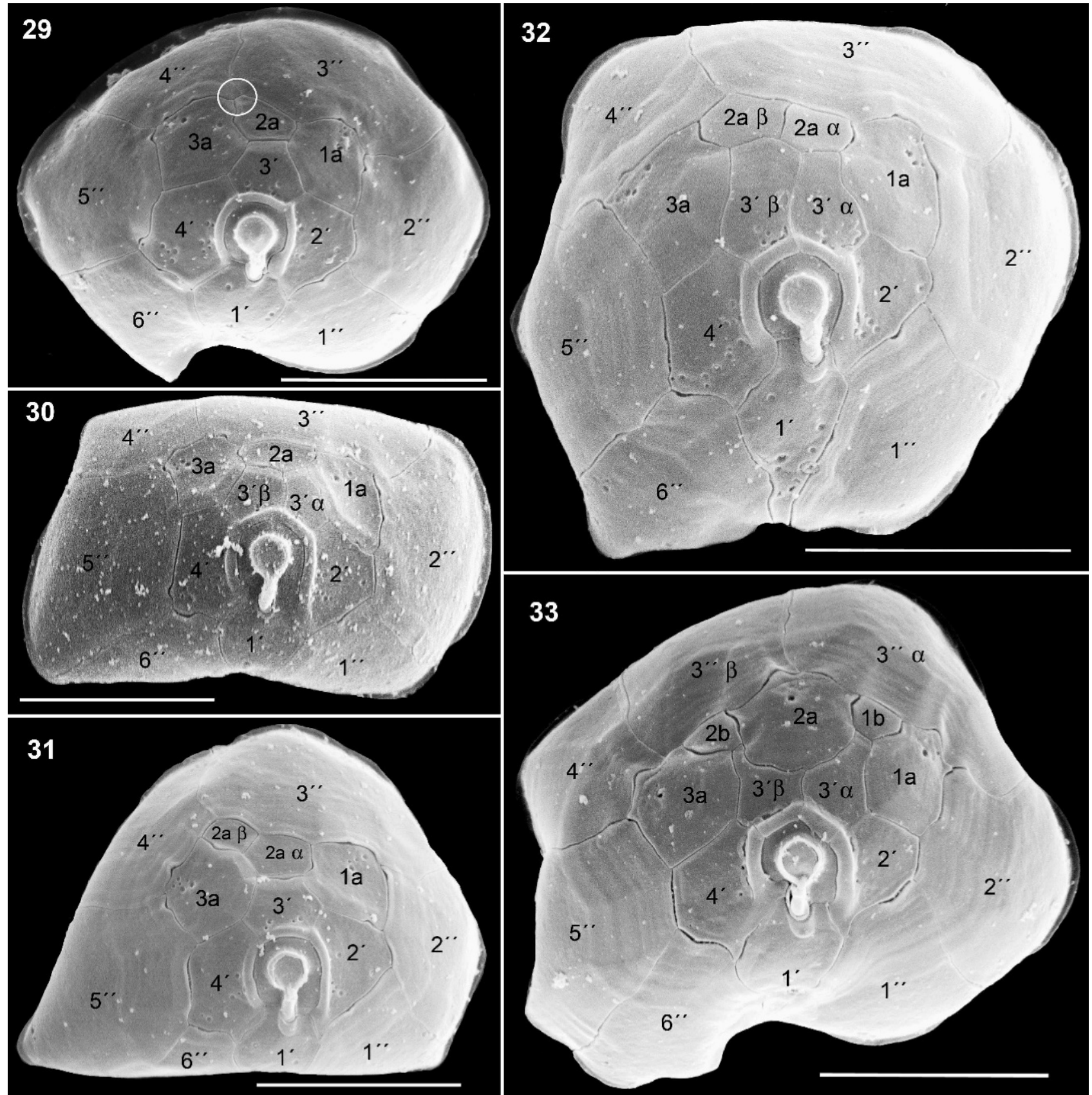

Also, in Fig. 35, the branch "Azadinium obesum 2E10 (XXXXXX)" should have read "Azadinium obesum 2E10 (FJ766093)", and in Fig. 36, the branch "Azadinium obesum 2E10 (XXXXXX)" should have read "Azadinium obesum 2E10 (GQ914937).”

A fully corrected version of the article is available online at www.phycologia.org. 